\title{
Organic Farming and Water Stress of Potatoes: Effects on Yield and its Components and Quality of French Fries
}

\author{
Hala A. Abd El-Aal ${ }^{1}$, Darwisch, W.Mohamed ${ }^{1}$, Naglaa, M. Ismaeil ${ }^{2}$ and Abu-Tour .S.M. ${ }^{2}$
}

\begin{abstract}
The present study was carried out at the Experimental Farm, University of Sadat City, Egypt for two successive seasons (2013/2014 and 2014/2015). Spastiano as a new Scotch potato cultivar in Egypt was used. The split plots in Complete Randomized Block Design (CRBD) was applied. The study aimed to investigate the effect of organic farming using natural spraying foliar ores of (biophertel $10 \mathrm{~g} / \mathrm{L}+$ Biocide $5 \mathrm{~g} / \mathrm{L}+$ bentocide $10 \mathrm{~g} / \mathrm{L}$ ) and $500 \mathrm{~kg} / \mathrm{fed}$ soil application with natural elements mixture versus the conventional farming under four levels of water stress $(100 \%, 80 \%, 60 \%$ and $50 \%$ of the ETc irrigation requirements) on potato. The significantly highest potato yield, size and number of tubers were figured out at irrigation level $100 \%$ ETc by conventional farming during season of 2014. The lowest values for the potatoes yield and its components characters were observed at irrigation level $50 \%$ ETc by organic farming. Increase water stress resulted in decline the aforementioned characters during the two seasons. No significant differences could be traced regarding texture and colour of tubers cultivated by organic and conventional farming at $100 \%$ Etc. Slight variation could be observed in terms of gross chemical composition of potato tubers cultivated by conventional and organic farming. No significant effect could be observed neither for type of farming nor water stress on sensorial acceptance of French fries. On the other hand, organic farming of potatoes resulted in lowering the oil retention in French fries.
\end{abstract}

Key Words: organic farming, potato yield, biophertel ore, Biocide ore, bentocide ore, natural elements mixture, water stress, oil retention, French fries

\section{INTRODUCTION}

Potatoes (Solanum tuberosum L.) are considered as an inexpensive source of energy along with some minerals, especially potassium. Potatoes possess high quality proteins in relation to other vegetable proteins (Burton, 1989). It is worth to mention that potatoes not only contain a great variety of nutrients, but also have many bioactive compounds such as flavonoids, carotenoids and phenolics, whose many beneficial effects on health have been recognized (Mouille \& Charrondiere, 2009 Wegner and Jansen 2015).

Potato products especially French fries are consumed by hundred millions of people worldwide and this has contributed to the vast growth and development of industrial and business dealing with their production (Kizito et al, 2015)

Organic potato tubers exhibited a significant enrichment in ${ }^{15} \mathrm{~N} \%$ when compared to their conventional counterparts. On the other hand, further parameters selected on the basis of reports of alteration as a consequence of agricultural technique- ascorbic acid, protein content and dry matter did not show consistent trends of variation throughout four field trials (Carmin et al., 2007).

Natural elements can be used to improve materials in the agricultural systems. For insance, Dolomit rock contains calcium and magnesium elements can be used in order to reduce salinity effects. Magnetite may play a key role in cations uptake capacity and has a positive effect on uptake of immobile plant nutrients (Esitkebn and Turon, 2003).

Potatoes grown for processing in irrigated regions of the pacific, North West, sometimes develop undesirably high concentrations of reducing sugars in tuber stem ends due to hot weather and water stress during tuber development according to Eldredge et al (1996). Increased reducing sugar concentrations were positively associated with decreased soil water potential (drier soil). Decreasing soil water potential (drier soil) was associated with progressively darker fry colours harvest and postharvest. The effect of imposed water stress on tuber stem-end reducing sugar concentration was most pronounced postharvest. The effect of water stress on potato growth development and yield was investigated by Loon (1981). Data indicated that the reduction of yield as a result of water stress can be caused by reduced leaf area and/or reduced photosynthesis per unit of leaf area. Water shortage during the tuber bulking period decreases yield to a larger extent than drought during other growth stages.

Zarzynska and Pictreaszko (2015) investigated the influence of climate conditions on development and yield of potato plants growing under organic and conventional system in Poland. This study was conducted in two seasons (2012 and 2013) with very different temperatures and rain fall patterns in Poland. It was found that in the poor growing year, total yield was reduced by $45 \%$ in conventional, but $55 \%$ in

\footnotetext{
1Environmental Studies and Research Institute, Univ. of Sadat City., Egypt.

${ }^{2}$ Food Science and Technology Department, Faculty of Agriculture,

University of Alexandria El- Shatby, Alex. 21545. Egypt

Received August 30, 2016, Accepted September 29, 2016
} 
organic tuber size was particularly impacted in organic production in an unfavorable year, as small tubers increasing by $39 \%$ in conventional but $149 \%$ in organic. Thus, the impact of unfavorable weather conditions led in greater losses in crop value for organic growing systems than conventional ones. In their extensive review article on quality attributes of French fries. kizito et al (2015) figured out the pivotal role of cultivation conditions, variety and postharvest technology practices on the quality attributes of French fries. Moreover, Sharara and Ghoneim (2015) reported significant effect of five potato varietis on gross chemical composition, dry matter, specific gravity, colour, polyphenols and ascorbic acid contents of potatoes.

The present study was carried out to investigate the effects of organic farming of potato and water stress on potatoes yield and its components and quality of tubers as well as the quality attributes of French fries versus their counterparts cultivated by traditional non-organic farming.

\section{MATERIALS AND METHODS}

Experimental work was conducted at the Experimental Farm Station of the Environmental Studies and Research Institute University of Sadat City, Minofiya Governorate, Egypt (Longitude $30^{\circ}$ and Latitude $30^{\circ} 25^{\circ}$ ). The soil texture of the experimental site was sandy loam with water field capacity of $19.22 \%$, welting point of $10.06 \%$, and bulk density of $1.45 \mathrm{gm} / \mathrm{cm}^{3}$. The physical and chemical properties of the experimental soil are presented in Table (1). The source of water of irrigation was a deep well.

\section{Analysis of irrigation water} (2).

Analysis of irrigation water used is given in Table

\section{Meteorological data:}

The air temperatures and relative humidity $(\mathrm{RH}$ $\%)$ through the two winter seasons were recorded and measured monthly by the Central Meteorological Lab, Ministry of Agriculture, Cairo (at Sadat City) are given in Table (3).

Table 1. The main physical and chemical properties of the experimental soil of 2012/2013 and 2013/2014 growing seasons

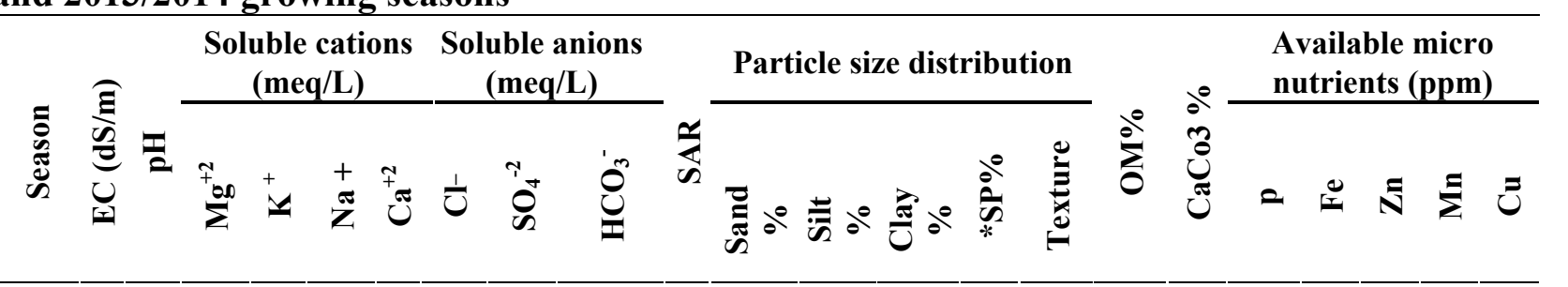

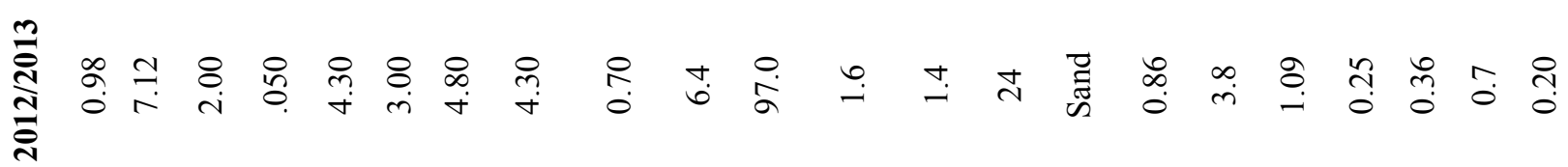

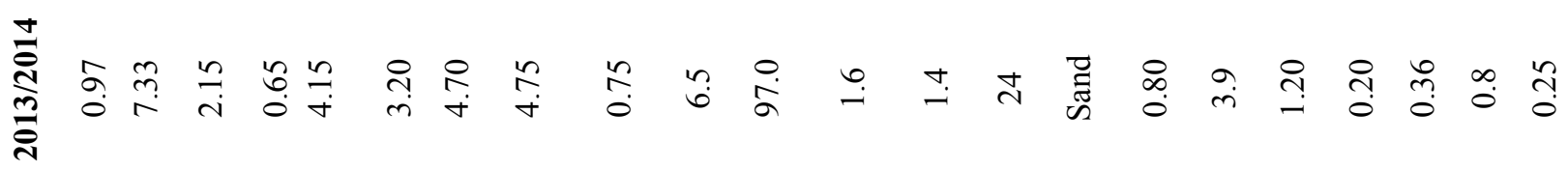

(*) Saturation percentage

These analyses were carried out at the Central Laboratory, Faculty of Agriculture Minufiya University.

Table 2. Chemical analysis of irrigation water during the two experimental seasons of

\begin{tabular}{|c|c|c|c|c|c|c|c|c|c|c|c|}
\hline \multirow[t]{2}{*}{ Season } & \multirow[t]{2}{*}{ pH } & \multirow{2}{*}{$\begin{array}{c}\text { EC } \\
\text { mhos/cm }\end{array}$} & \multicolumn{4}{|c|}{ Cations(MEq/l) } & \multicolumn{4}{|c|}{ Anions(MEq/l) } & \multirow[b]{2}{*}{ SAR } \\
\hline & & & $\mathrm{Ca}^{++}$ & $\mathbf{M g}^{++}$ & $\mathbf{N a}^{++}$ & $\mathbf{K}^{+}$ & $\mathrm{CO3}^{-}$ & $\mathrm{HCO3}^{-}$ & $\mathrm{Cl}^{-}$ & $\mathrm{SO}^{--}$ & \\
\hline $2012 / 2013$ & 7.13 & 456.0 & 1.99 & 2.17 & 0.96 & 1.38 & 0.0 & 1.02 & 1.25 & 0.87 & 0.95 \\
\hline $2013 / 2014$ & 7.20 & 468.7 & 2.09 & 2.46 & 1.32 & 1.41 & 0.0 & 1.03 & 1.61 & 1.05 & 1.24 \\
\hline
\end{tabular}
2012/2013 and 2013/2014

These analyses were carried out at the Central Laboratory, Faculty of Agriculture Minufiya University. 
Table 3. Maximum, minimum and monthly average temperature $\left({ }^{\circ} \mathrm{C}\right)$ and relative humidity (RH \%) during both seasons of 2012/2013 and 2013/2014 in Sadat City

\begin{tabular}{|c|c|c|c|c|c|c|c|c|c|c|c|}
\hline & \multirow{2}{*}{$\begin{array}{l}\text { Month } \\
\text { Season } \\
\end{array}$} & \multicolumn{2}{|c|}{ October } & \multicolumn{2}{|c|}{ November } & \multicolumn{2}{|c|}{ December } & \multicolumn{2}{|c|}{ January } & \multicolumn{2}{|c|}{ February } \\
\hline & & first & second & first & second & first & second & first & second & first & second \\
\hline \multirow{3}{*}{ 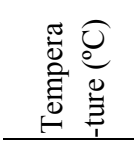 } & Min. & 14.19 & 15.22 & 11.24 & 12.30 & 4.9 & 5.5 & 4.7 & 5.3 & 5.3 & 6.0 \\
\hline & Max. & 28.59 & 28.60 & 24.23 & 25.21 & 21.3 & 19.9 & 18.2 & 17.4 & 19.3 & 18.2 \\
\hline & Avar. & 20.7 & 21.18 & 16.87 & 17.11 & 13.1 & 12.7 & 11.4 & 11.3 & 12.3 & 12.1 \\
\hline \multirow{3}{*}{ 衤 } & Min & 42.3 & 44.6 & 55.2 & 46.9 & 44.3 & 41.6 & 50.2 & 44.9 & 47.5 & 46.2 \\
\hline & Max & 72.2 & 67.7 & 78.2 & 44.6 & 70.2 & 69.7 & 76.2 & 41.6 & 74.3 & 72.3 \\
\hline & Avar. & 57.2 & 5.6 & 66.7 & 45.75 & 57.2 & 55.6 & 63.2 & 75.1 & 63.1 & 59.2 \\
\hline
\end{tabular}

The experiments were conducted in October, 15, 2013 and 2014 and the small potato tubers $(60 \mathrm{gm})$ were planted, at a spacing of $0.25 \times 1.2 \mathrm{~m}$ within and between rows. For fertilization, the experiment was divided into two separate plots. Conventional farm was used only in one plot, while organic farm as a Natural Element Mixture) and foliar spraying with natural ore from mining and installation company El-Ahram was used in the other plot. Levels of $100 \%, 85 \%, 60 \%, 50 \%$ of the ETc irrigation requirements were distributed in sub plots. The area of each experimental plot was

$\left(4 \mathrm{~m}\right.$. L x 3 rows $\times 1.4 \mathrm{~m}$. W. $\left.=16.8 \mathrm{~m}^{2}\right)$. Distance between two plants was $25 \mathrm{~cm}$.

The drip irrigation was applied in the present work.

\section{Experimental design and treatments}

In the present study, the following treatments were carried out:

\section{1- Farming type (main plots):}

a -Organic farming: Eight-ton animal compost/fed. + $500 \mathrm{~kg} /$ fed Natural Element Mixture (NEM) was applied as soil application (Table 4) and foliar spraying with natural ores of biophertel $10 \mathrm{~g} / \mathrm{L}+$ Biocide $5 \mathrm{~g} / \mathrm{L}+$ bentocide $10 \mathrm{~g} / \mathrm{L}(\mathrm{A}+\mathrm{B}+\mathrm{D})$ were applied to organic farming treatments at regular interval period of two weeks after month from planting (duration from November, 15 to 15 febreuary).

b -Conventional farming: Foliar spraying with distilled water and (without Natural Element Mixture NEM). Common fertilizers were applied at the amounts of control: recommended doses were 8ton animal compost / fed added at soil preparation directly before ridging. The mineral fertilizers were applied uniformly as follows: $150 \mathrm{~kg} / \mathrm{fed}$ superphosphates $\left(15.5 \% \mathrm{P}_{2} \mathrm{O}_{5}\right)$ was added during soil preparation, $50 \mathrm{~kg}$ potassium sulphate $(48 \%$ $\left.\mathrm{K}_{2} \mathrm{O}\right)+100 \mathrm{~kg} /$ fed urea $(46 \% \mathrm{~N})$ were applied after one month from sowing and $100 \mathrm{~kg}$ potassium sulphate $+100 \mathrm{~kg} / \mathrm{fed}$ Urea after three months of sowing date.

\section{2- Water stress (sub plots):}

- Four irrigation treatments were applied (ET1: irrigation level 1 as full crop evapotranspiration (100\% ETc), level 2(85\% ETc), level 3 (60\% ETc) and level $4(50 \%$ ETc). Irrigation water was delivered via a drip irrigation system. The emitters used in the drip irrigation system have flow rate of 4 $\mathrm{L} / \mathrm{hr}$. The emitters were spaced at $30 \mathrm{~cm}$ with polyethylene tubes $(16 \mathrm{~mm}$ in external diameter with $20 \mathrm{~m}$ in length).

The potatoes were arranged in a split- plots in Completely Randomized Block Design (CRBD) experiment with three replicates.

\section{Irrigation water requirement}

The FAO Penman-Monteith method (Allen et al., 1998) was used to calculate the reference evapotranspiration $\mathrm{ET}_{\mathrm{o}}$ in the CROPWAT Program. Crop water requirements $\left(\mathrm{ET}_{\mathrm{c}}\right)$ over the growing season were determined from $\mathrm{ET}_{\mathrm{o}}$ according to the following equation using crop coefficient $\mathrm{K}_{\mathrm{c}}$ :

$E T_{c}=K_{c} . E T_{o}$

Where $\mathrm{ET}_{\mathrm{c}}$ is the crop water requirement, $\mathrm{K}_{\mathrm{c}}$ is the crop coefficient and $\mathrm{ET}_{\mathrm{o}}$ is the reference evapotranspiration. Since, there was no rainfall during the experimental period, net irrigation requirement was taken to be equal to $\mathrm{ET}_{\mathrm{c}}$. The total amounts of irrigation water applied (from transplantation to harvest) in the present study were 2760, 2350, 1659 and $1382 \mathrm{~m}^{3} / \mathrm{fed}$ and $2912,2475,1747$ and $1456 \mathrm{~m}^{3} /$ fed as irrigation level 1 (100\% ETc), level 2 (85 ETc), level 3 $(60 \% \mathrm{ETc})$ and level $4(50 \% \mathrm{ETc})$ in the studied seasons 2012/ 2013 and 2013/2014, respectively. The water requirement was determined for different months based on crop growth stages and climatic data.

\section{Water use efficiency}

Water use efficiency WUE $\left(\mathrm{Kg} / \mathrm{m}^{3}\right)$ was calculated as fresh potato yield divided by seasonal ETc (amount of water added) (Tanner and Sinclair, 1983; Howell et al., 1990). 
Table 4. Chemical analysis of natural ores \% (mixture natural minerals \%, Biocide \%, Bentocide \% and Biophertil \% ores) ${ }^{*}$

\begin{tabular}{lcccccccccccc}
\hline Item & $\mathbf{S i O}_{2}$ & $\mathbf{T i O}_{2}$ & $\mathbf{A L}_{2} \mathbf{O}_{3}$ & $\mathbf{F e}_{2} \mathbf{O}_{3}$ & $\mathbf{M n O}$ & $\mathbf{M g O}$ & $\mathbf{C a O}$ & $\mathbf{N a}_{2} \mathbf{O}$ & $\mathbf{K}_{2} \mathbf{O}$ & $\mathbf{P}_{2} \mathbf{O}_{5}$ & $\mathbf{S O}_{3}$ & $\mathbf{C I}$ \\
\hline $\begin{array}{l}\text { Mixture } \\
\text { mineral s \% }\end{array}$ & 39.35 & 0.80 & 7.675 & 4.05 & 0.67 & 3.19 & 15.05 & 1.75 & 4.24 & 7.33 & 5.81 & - \\
\hline Biocide\% & - & 0.85 & 7.80 & 4.52 & 0.74 & 3.92 & 16.69 & 2.19 & 4.51 & 8.52 & 6.28 & - \\
\hline Bentocide\% & - & 0.33 & 6.55 & 5.49 & 1.61 & 2.17 & 21.45 & 1.06 & 0.56 & 0.45 & 12.52 & 0.45 \\
\hline Biophertil\% & - & - & - & 6.70 & 0.24 & 28.03 & 69.03 & - & 0787.50 & - & - & - \\
\hline
\end{tabular}

*This analysis has been through El-Ahram Company at National Center for Research in 2012

\section{Recorded data:}

Potatoes yield and its components: Samples from the potatoes crop were taken from the field to obtain the mean yield for each irrigation level under organic and conventional fertilizer for the two seasons (2013 and 2014). Square wooden frame of an area of $1 \mathrm{~m}^{2}$ was used as a sampling tool. The potato yield samples were taken randomly from each plot, and then the potato yields production/fed. were separately evaluated as follows.

-Total yield of tubers / plant (Kg).

- Total yield of tubers / fed. (ton)

- Number of tubers /plant.

-Average tuber weight (gm)

-Size of tubers: Width - length $(\mathrm{cm})$.

\section{Technological methods:}

Potato tubers were thoroughly washed, hand-peeled using stainless steel knives to remove a thin outer layer of peel. Thereafter, tubers were cut along axis to fingers of $6-8 \mathrm{~cm}$ for length and $0-5-1-.0 \mathrm{~cm}$ in width. Potato fingers (French fries) were deep fried in cotton seed oil at $180^{\circ} \mathrm{C}$ for $10 \mathrm{~min}$.

\section{Sensory evaluation}

Fried potatoes were evaluated by panelists from Food Science and Technology Department, Faculty of Agriculture, University of Alexandria. They were asked to score the samples regarding colour, taste, odour, texture and overall acceptability, according to a standard hedonic rating scale from I (dislike extremely) to 9 (like extremely) as outlined by Kramer and Twig (1970).

\section{Physical characteristics \\ Colour measurement:}

The colour parameters which include: Lightness $\left(\mathrm{L}^{*}\right)$ redness $\left(\mathrm{a}^{+}\right)$, yellowness $\left(\mathrm{b}^{+}\right)$, chroma $(\mathrm{c})$ and hue (h) of fried potato fingers were measured by Hunter Lab Ultra Scan VIS model colorimeter (USA).

\section{Texture measurement:}

The following texture parameters were measured for the fried potato usingBrookfield Engineering Labs, Inc. Hardness $(\mathrm{g})$, deformation at hardness $(\mathrm{mm})$, hardness work (mj), total work (mj), recoverable deformation cycle (mm) and time for penetration $10 \mathrm{~mm}(\mathrm{~s})$.

\section{Bulk density:}

It is the amount of potatoes occupied a certain volume of space $\left(\mathrm{g} / \mathrm{cm}^{3}\right)$. Bulk density was determined according to the method of Rangana (1977).

\section{Analytical methods:}

Chemical composition (moisture, crude protein, ash, total lipids, oil retention and total carbohydrate contents were determined as described in AOAC (2003).

Oil retention in fried potato fingers was determined by Folch method using a mixture of methanol and chloroform (2:1)

\section{Statistical analysis:}

A split plot in Completely Randomized Block Design (CRBD) experiment with three replicates. The t-test and analysis of variance (ANOVA) of treatments and L.S.D were performed according to Steel and Torrie (1980). The used procedures are viable within the SAS software package (Version 9.13, 2008).

\section{RESULTS AND DISCUSSIONS}

\section{Total tubers yield / plant (kg)}

Figure 1 shows that the total tubers yield/plant was significantly achieved for conventional farming at $100 \%$ irrigation level in both seasons. No significant difference could be traced in this character for conventional farming at $85 \%$ irrigation level in the first season. It is clears that organic farming at the four irrigation levels exhibited lower total tubers yield/plant than their counterparts for conventional farming especially in the first. It is worth to mention that data presented here regarding potato production are contradictory to onions cultivated under the same conditions. In other words, organic farming gave the highest onions yield/plant as compared to conventional 
farming (El- Hanafy, 2016). Such a variation can be attributed to use liquid ammonium nitrate $(33.5 \%)$ in his study for plant nutrition during growth seasons which resulted in achieving higher onions/plant.

Total tubers yield (ton / feddan):

Figure (2) shows the total tubers yield (ton/ fed.) during the two studied seasons (2012 / 2013 and 2013 / 2014) for different irrigation levels under organic and conventional fertilizers by using drip irrigation system. The highest potatoes yield (19.7 ton/fed.) was observed with irrigation level 1 (100\% ETc) and conventional fertilization during 2013 / 2014 season, while the lowest (5.32 ton/fed.) was due to irrigation by level 4 $(50 \%$ ETc) and organic fertilizer during the first season of 2012/ 2013. The lowest value of total tubers yield / fed. was associated with low number of tuber / plant and low increase in the number of tuber size and average tubers weight $(0.29 \mathrm{Kg} /$ plant $)$. Generally, the variation in total tubers yield of potatoes ton /fed. was positively correlated with the number and size of tubers per plant.

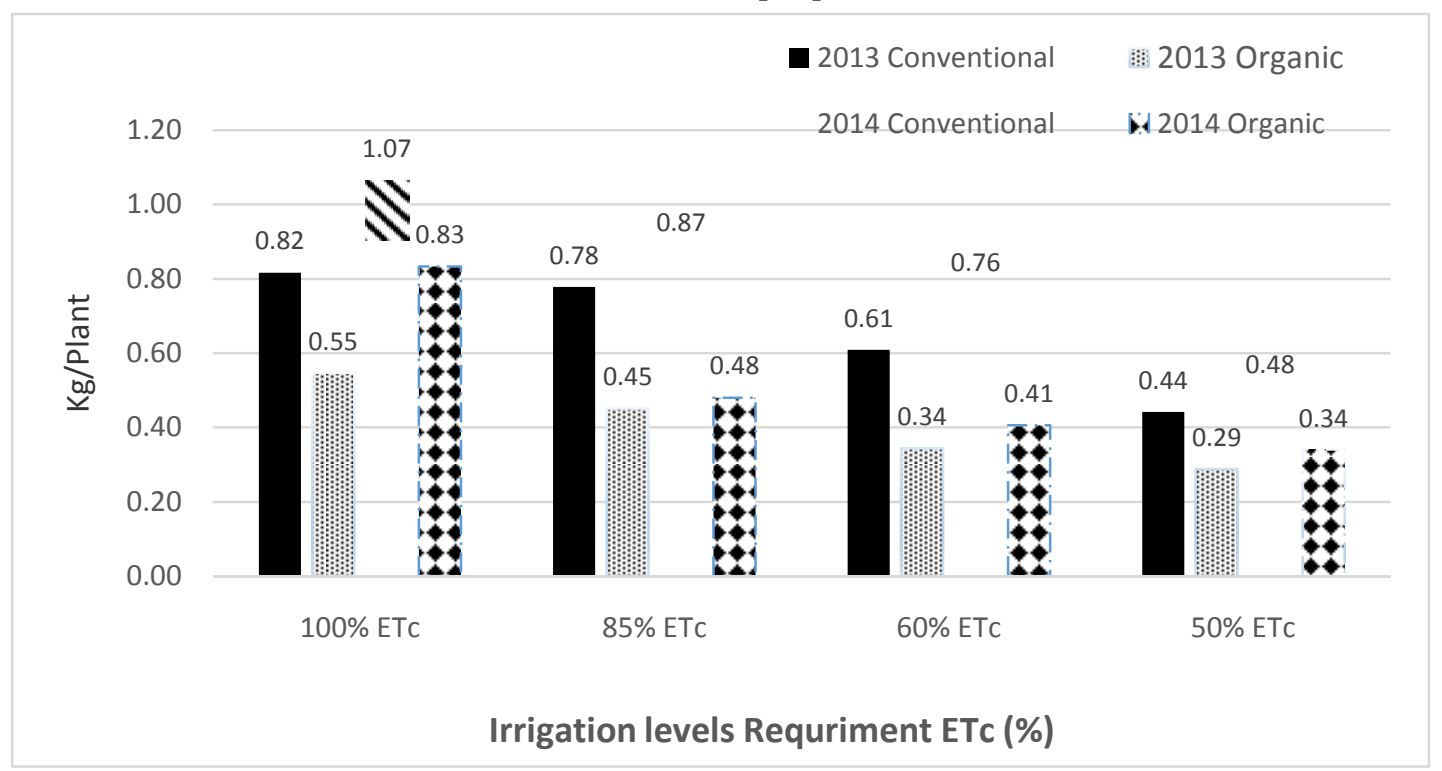

Fig 1. Comparison of total tubers yield/ plant for irrigation regime levels under organic and conventional farming during the two seasons of cultivation

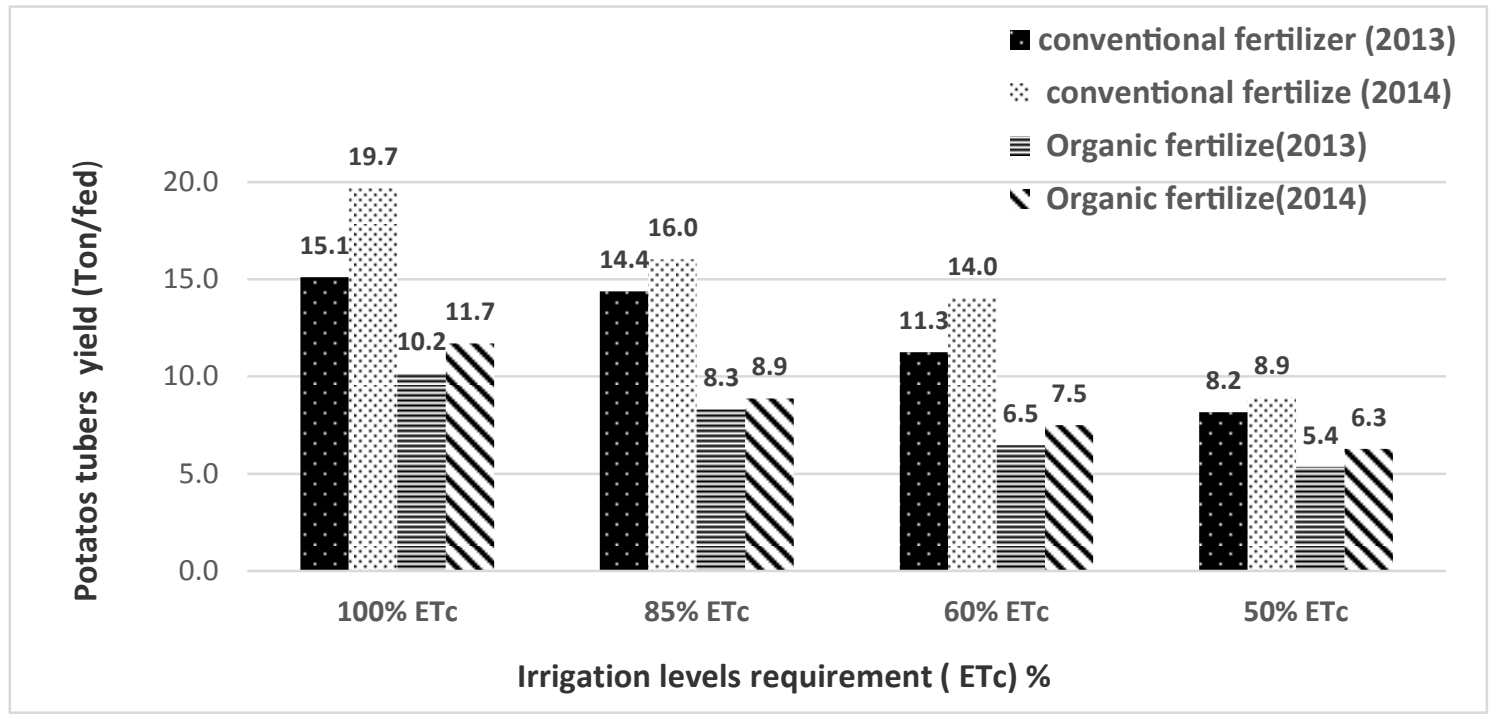

Fig 2. Comparison of potato tubers production/fad. for irrigation regime levels under organic and conventional farming during the two seasons of cultivation 
Also, similar association has been observed in the irrigation levels 2,3 and $4(85 \%, 60 \%$ and $50 \%$ of ETc, respectively), where water stress has reduced total potatoes yield. Moreover, it can be noted that, the highest totat potatoes yield ton /fed was achieved for full irrigation $(100 \%$ ETc) and $(85 \%$ ETc) under conventional fertilizer during season 2014 (19.7 and 16.02 ton/fed.), when comparing with the same statements during season 2014 under organic fertilizer. These results may be due to the improvement of the soil properties and more added water in season 2014. Finally, it can be concluded that, potatoes yield production was more effected by water stress and added organic fertilizer only.

Regarding the effect of irrigation levels and type of fertilizer added, the results in Fig. 3 clearly showed that irrigation levels significantly affected number of tubers/plant, total tubers yield/fed, as well as water use efficiency (WUE $\mathrm{kg} / \mathrm{m}^{3}$ ) in both seasons. Increasing water stress from level 1 (2760 and $2912 \mathrm{~m}^{3}$ water/fed) to level 4 (1382 and $1456 \mathrm{~m}^{3}$ water/fed) during seasons 2013 and 2014, respectively resulted in a decrease of the number of tubers/plant, total tuber yield/ fed, in both seasons. Irrigation level $3 \quad(60 \%$ ETc $) \quad(1747$ $\mathrm{m}^{3}$ water/fed) under inorganic fertilizer during season 2014 exhibited the highest WUE $\left(8 \mathrm{Kg} / \mathrm{m}^{3}\right)$. On the other hand, irrigation level 2 (85\% ETc) (2350 and $2475 \mathrm{~m}^{3}$ water/fed) under organic fertilizer for both seasons 2013 and 2014, produced the lowest values of WUE $\left(3.5\right.$ and $\left.3.6 \mathrm{~kg} / \mathrm{m}^{3}\right)$ in both seasons, respectively. In general, the increases in total tubers yield ton/fed due to increases in irrigation water added and inorganic fertilizer might be due to increases in tubers number /plant and averages of tuber weight. Moreover, total tubers yield increased considerably due to increasing in availability of water. Similar results were found by Hassan et al. (2002) who stated that potato yield was significantly influenced by variation in irrigation water treatments and plot receiving high amount of irrigation water had high tuber yield compared with the other low amount of irrigation water. In accordance, several studies have reported increase in WUE due to the increase in water stress (Badr et al., 2010; Hassanpanah, 2010; Badr et al., 2012).

\section{Average tuber numbers /plant}

Fig. 4 shows that the effect of irrigation levels and fertilization types on tubers number per plant under studied seasons. Results showed that the average values of tubers number during the two seasons of 2012/2013 and 2013 / 2014 for different levels of irrigation system by using mineral fertilizer was significantly higher than that obtained during the two seasons using organic fertilizer. Moreover, it has been noted that the maximum values for number of tubers /plant of potato were 18.2 and 15.6 tubers/plant under $100 \%$ evapotranspiration and mineral fertilizer, while the minimum values were 5.63 and 5.39 tubers/plant under $50 \%$ evapotranspiration and organic fertilizer during the two seasons of 2012/ 2013 and 2013 / 2014, respectively. This indicates that the higher number of tubers/plant was in associated with increasing amount of water applied and mineral fertilizer.

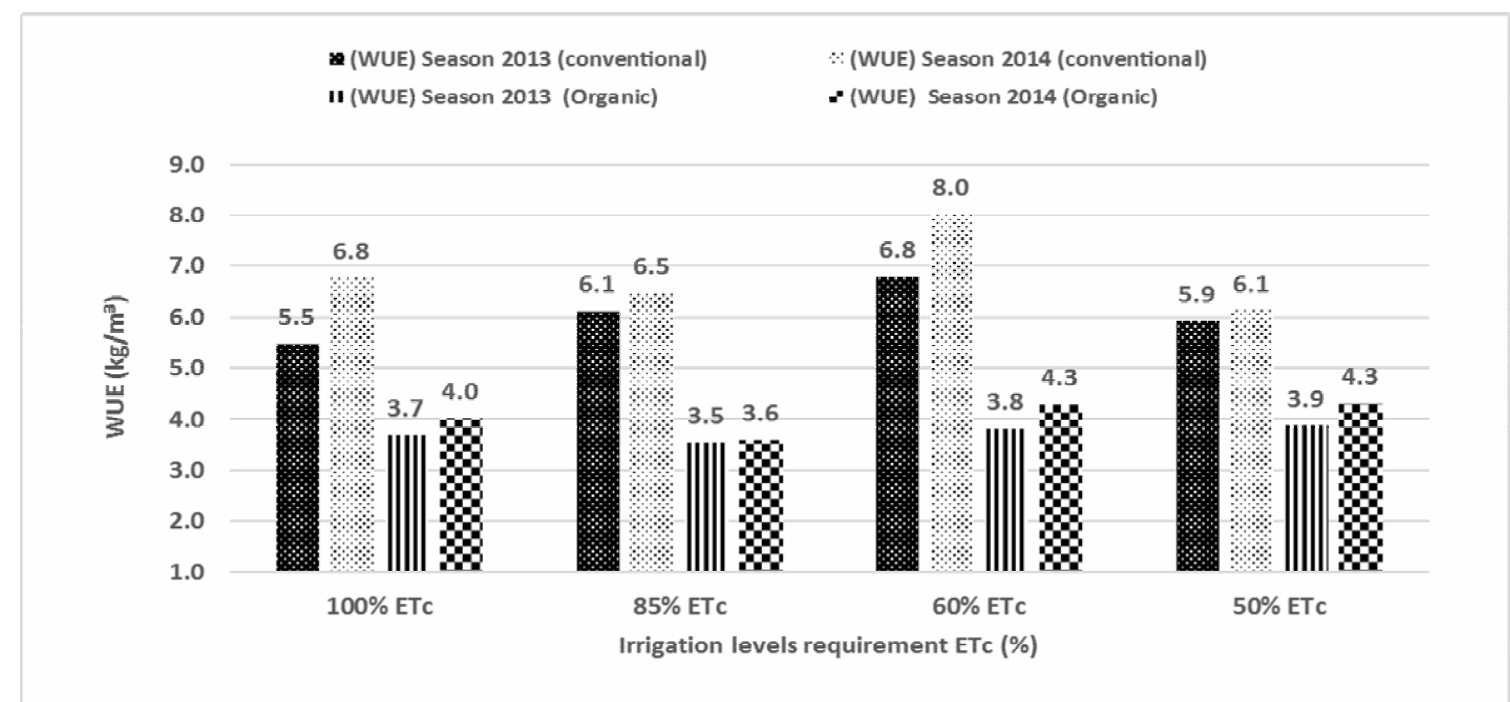

Fig 3. Water use efficiency for irrigation regime levels under organic and conventional farming during the two seasons of potato cultivation 


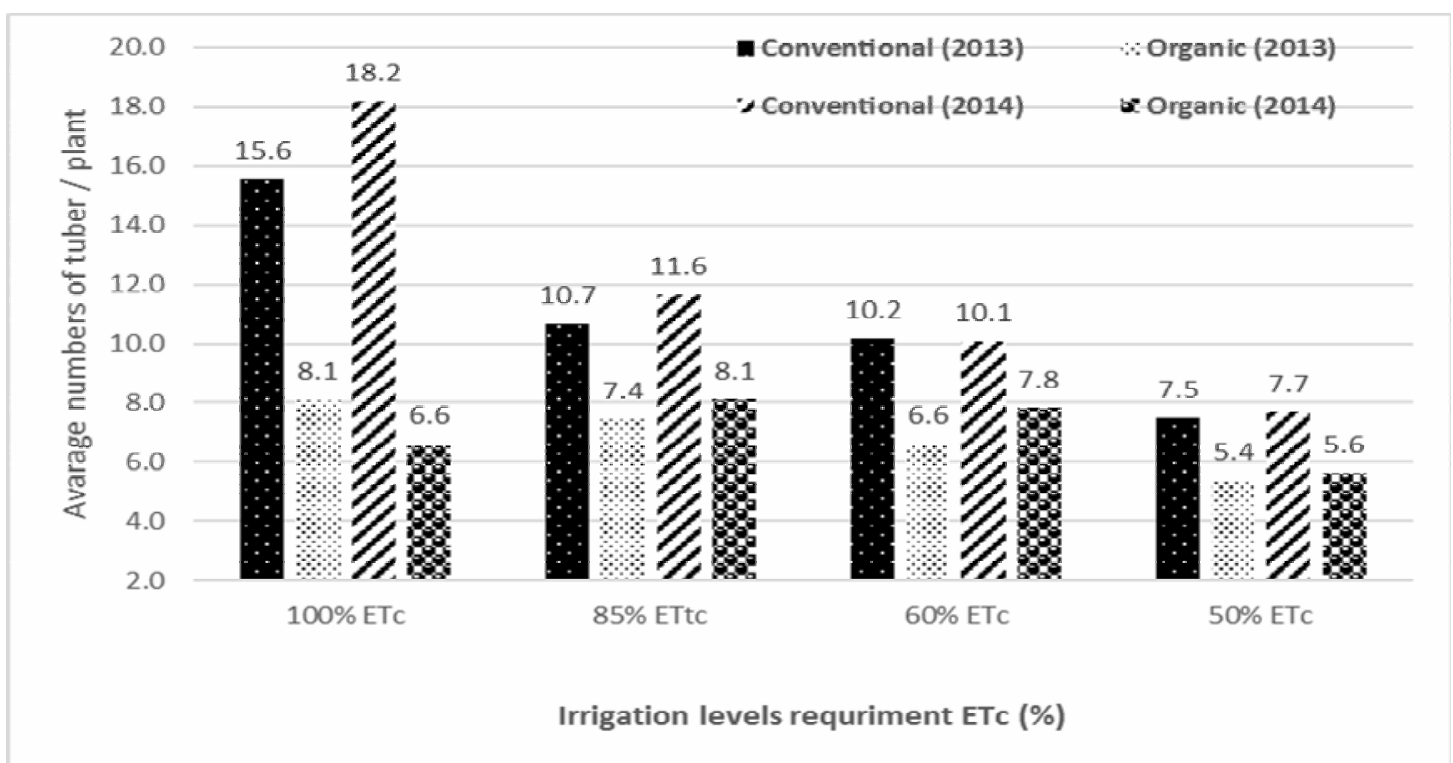

Fig 4. Effect of irrigation levels and farming type (conventional and organic) on tubers number/plant during the two seasons of 2012/ 2013 and 2013 / 2014

Average weight of tuber (gm)

Fig.5 illustrates the effect of irrigation levels and fertilization types on weight of tuber during the studied seasons (2012/ 2013 and 2013/2014). It was obvious that, the maximum weight of potato tuber was achieved under irrigation level (1) (100\% ETc) and conventional farming (150.4 gm. / tuber) during the second season of 2013/2014. The minimum weight of potato tuber was achieved under irrigation level (4) $(50 \%$ ETc) and organic fertilizer (42.7 gm/tuber) during season 2013. Also, it can be observed that there is a convergence in the weight of tubers under irrigation level $2(85 \% \mathrm{ETc})$ by using conventional and organic farming $(72.6,70.21$, 75 and $73.01 \mathrm{gm} /$ tuber) during the two studied seasons of 2012 / 2013 and 2013/2014, respectively, Finally, it can be concluded that, the high values of potato tubers/plant were in found treatments with increasing amount of water applied and mineral fertilizer. Also, this variety of potato (Spastiano) is more suitable for achievement of medium-weight tubers under less stress water $(85 \% \mathrm{ETc})$ for conventional or organic farming.

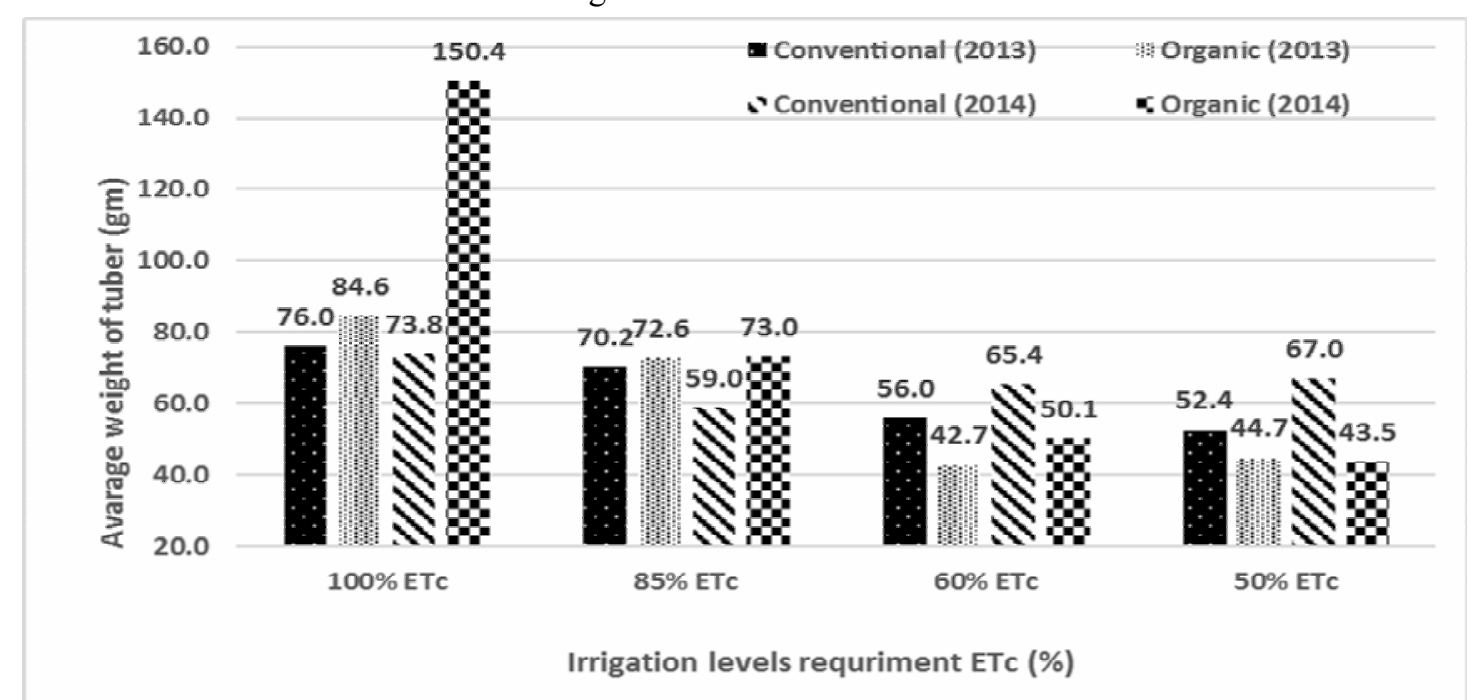

Fig 5. Effect of irrigation levels and farming types (conventional and organic) on average weight of tuber during the two seasons of $2012 / 2013$ and 2013 / 2014 
Sensory Quality and oil retention of French fries: -

Potato tubers cultivated by both organic and conventional (inorganic) at different values of water stress were utilized to prepare French fries. Data presented in Table (4) show that no significant effect neither for type of farming nor for water stress could be traced in terms of sensorial acceptance of French fries. This was true for colour, taste, odour, consistency and overall acceptability as jugged by panelists.
Texture of potato tubers as affected by type of farming and water stress: -

Table (5) shows texture parameters of potato tubers cultivated by organic and conventional farming at different values of water stress. Data indicated that potato tubers cultivated by organic and conventional farming at $100 \%$ irrigation level possessed significantly the highest values of hardness, hardness work and total work as compared to all other treatments cultivated by both types of farming at different water stress values.

Table 4. Sensory evaluation and oil retention of French fries belonging to potato tubers cultivated by organic and conventional farming at different levels of water stress

\begin{tabular}{lcccccc}
\hline Farming type & Water stress & colour & taste & odour & consitstency & overall \\
\hline organic & 100 & $9.6^{\mathrm{a}} \pm .99$ & $9^{\mathrm{a}} \pm .95$ & $9.1^{\mathrm{a}} \pm .84$ & $8.9^{\mathrm{a}} \pm .92$ & $9.1^{\mathrm{a}^{2} \pm .96}$ \\
\cline { 2 - 7 } & 85 & $9.3^{\mathrm{a}} \pm .54$ & $8.9^{\mathrm{a}} \pm .88$ & $9.4^{\mathrm{a}} \pm .77$ & $9.5^{\mathrm{a}} \pm .63$ & $9.14^{\mathrm{a}} \pm .5$ \\
\cline { 2 - 7 } & 60 & $9.0^{\mathrm{a}} \pm .73$ & $8.8^{\mathrm{a}} \pm .67$ & $9.1^{\mathrm{a}} \pm .88$ & $9^{\mathrm{a}} \pm .49$ & $8.9^{\mathrm{a}} \pm .77$ \\
\cline { 2 - 7 } & 50 & $9.0^{\mathrm{a}} \pm .77$ & $8.5^{\mathrm{a}} \pm .45$ & $9^{\mathrm{a}} \pm .78$ & $9.2^{\mathrm{a}} \pm .90$ & $8.8^{\mathrm{a} \pm .78}$ \\
\hline conventional & 100 & $9.2^{\mathrm{a}} \pm .81$ & $9^{\mathrm{a}} \pm .89$ & $8.6^{\mathrm{a}} \pm .56$ & $9.4^{\mathrm{a}} \pm .81$ & $8.9^{\mathrm{a}} \pm .71$ \\
\cline { 2 - 7 } & 85 & $9.3^{\mathrm{a}} \pm .7$ & $8.8^{\mathrm{a}} \pm .9$ & $9^{\mathrm{a}} \pm .70$ & $8.9^{\mathrm{a}} \pm .67$ & $9^{\mathrm{a}} \pm .87$ \\
\cline { 2 - 7 } & 60 & $8.9^{\mathrm{a}} \pm .91$ & $9.1^{\mathrm{a}} \pm .64$ & $8.6^{\mathrm{a}} \pm .88$ & $8.4^{\mathrm{a}} \pm .99$ & $9.4^{\mathrm{a}} \pm .78$ \\
\cline { 2 - 6 } & 50 & $8.8^{\mathrm{a}} \pm .66$ & $9^{\mathrm{a}} \pm .98$ & $8.9^{\mathrm{a}} \pm .97$ & $9.3^{\mathrm{a}} \pm .49$ & $9.2^{\mathrm{a}} \pm .56$ \\
\hline
\end{tabular}

Means in a column not sharing the same superscript are significantly different at $\mathrm{P}>0.05$

Table 5. Texture parameters of potato tubers cultivated by organic and conventional farming at different levels of water stress

\begin{tabular}{|c|c|c|c|c|c|c|c|}
\hline \multirow{2}{*}{\multicolumn{2}{|c|}{ Treatment }} & \multicolumn{6}{|c|}{ Texture parameters } \\
\hline & & 1 & 2 & 3 & 4 & 5 & 6 \\
\hline \multicolumn{2}{|l|}{ Organic farm. } & $962.50 \mathrm{a}$ & $1.12 \mathrm{~b}$ & $65.0 \mathrm{a}$ & $66.0 \mathrm{a}$ & $0.37 \mathrm{~b}$ & $43.75 \mathrm{~b}$ \\
\hline \multicolumn{2}{|c|}{ Conventional farm } & $898.25 \mathrm{a}$ & $1.44 \mathrm{a}$ & $59.42 \mathrm{~b}$ & $60.10 \mathrm{~b}$ & $0.42 \mathrm{a}$ & $50.12 \mathrm{a}$ \\
\hline \multicolumn{2}{|l|}{ L.S.D 0.05} & - & 0.02 & 0.12 & 0.35 & 0.02 & 1.21 \\
\hline \multicolumn{8}{|l|}{ Water stress } \\
\hline \multicolumn{2}{|l|}{$100 \%$} & $956.33 \mathrm{a}$ & $1.45 \mathrm{~b}$ & $64.55 \mathrm{~b}$ & $65.30 \mathrm{a}$ & $0.38 \mathrm{c}$ & $50.00 \mathrm{a}$ \\
\hline \multicolumn{2}{|l|}{$85 \%$} & $911.50 \mathrm{a}$ & $0.97 \mathrm{~d}$ & $57.15 \mathrm{~d}$ & $58.00 \mathrm{c}$ & $0.29 \mathrm{~d}$ & $43.50 \mathrm{~b}$ \\
\hline \multicolumn{2}{|l|}{$60 \%$} & $958.00 \mathrm{a}$ & $1.53 \mathrm{a}$ & $62.35 \mathrm{c}$ & $63.35 \mathrm{~b}$ & $0.41 \mathrm{~b}$ & $44.00 \mathrm{~b}$ \\
\hline \multicolumn{2}{|l|}{$50 \%$} & $895.66 \mathrm{a}$ & $1.17 \mathrm{c}$ & $64.80 \mathrm{a}$ & $65.55 \mathrm{a}$ & $0.50 \mathrm{a}$ & $50.00 \mathrm{a}$ \\
\hline \multicolumn{2}{|l|}{ L.S.D.0.05 } & - & 0.02 & 0.17 & 0.49 & 0.03 & 1.7 \\
\hline \multicolumn{8}{|l|}{ Interactions: } \\
\hline \multicolumn{2}{|l|}{ Farming type } & 1 & 2 & 3 & 4 & 5 & 6 \\
\hline \multirow[t]{4}{*}{ organic } & 100 & $1065.66 \mathrm{a}$ & $1.38 \mathrm{c}$ & $75.80 \mathrm{a}$ & $76.80 \mathrm{a}$ & $0.41 \mathrm{c}$ & $50 \mathrm{a}$ \\
\hline & 85 & $1057.00 \mathrm{a}$ & $1.07 \mathrm{e}$ & $57.20 \mathrm{e}$ & $58.30 \mathrm{e}$ & $0.27 \mathrm{f}$ & $37 \mathrm{a}$ \\
\hline & 60 & $942.00 \mathrm{ab}$ & $0.88 \mathrm{f}$ & $68.50 \mathrm{c}$ & $69.90 \mathrm{c}$ & $0.37 \mathrm{~cd}$ & $38 \mathrm{a}$ \\
\hline & 50 & $785.33 b$ & $1.17 \mathrm{~d}$ & $58.50 \mathrm{~d}$ & $59.00 \mathrm{~d}$ & $0.44 \mathrm{bc}$ & $50 \mathrm{a}$ \\
\hline \multirow[t]{4}{*}{ conventional } & 100 & $847.00 \mathrm{~b}$ & $1.54 \mathrm{~b}$ & $53.30 \mathrm{~g}$ & $53.80 \mathrm{~g}$ & $0.35 \mathrm{~d}$ & $50 \mathrm{a}$ \\
\hline & 85 & $766.00 \mathrm{~b}$ & $0.88 \mathrm{f}$ & $57.10 \mathrm{e}$ & $57.70 \mathrm{e}$ & $0.31 \mathrm{e}$ & $50 \mathrm{a}$ \\
\hline & 60 & $974.00 \mathrm{ab}$ & $2.18 \mathrm{a}$ & $56.20 \mathrm{f}$ & $56.80 \mathrm{f}$ & $0.46 \mathrm{~b}$ & $50 \mathrm{a}$ \\
\hline & 50 & $1006.00 \mathrm{ab}$ & $1.17 \mathrm{~d}$ & $71.10 \mathrm{~b}$ & $72.10 \mathrm{~b}$ & $0.56 \mathrm{a}$ & $50 \mathrm{a}$ \\
\hline \multicolumn{2}{|l|}{ L.S.D.0.05 } & 178.24 & 0.01 & 0.24 & 0.70 & 0.04 & 2.4 \\
\hline $3=$ Hardness, work $1(\mathrm{~mJ})$ & $\begin{array}{l}\mathrm{mJ}) \\
\text { mation }(\mathrm{mm})\end{array}$ & $\begin{array}{l}2=I \\
4=7 \\
6=7\end{array}$ & $\begin{array}{l}\text { ormation } \\
\text { al work1 } \\
\text { le for per }\end{array}$ & $\begin{array}{l}\text { dness }(\mathrm{mr} \\
\text { on } 10 \mathrm{~mm}\end{array}$ & & & \\
\hline
\end{tabular}


On the other hand, higher deformation at hardness was observed significantly for tubers cultivated by conventional farming at $60 \%$ water stress, while tubers cultivated by conventional farming at $50 \%$ water stress had significantly the highest hardness and recoverable deformation. Meanwhile, no significant difference could be observed regarding tuber cultivated by organic farming. No significant difference was observed concerning the time for penetration $10 \mathrm{~mm}$ (s) for tubers cultivated by conventional farming at all levels of water stress. On the other hand, the significantly higher time for penetration was observed for tubers cultivated by organic farming at $50 \%$ water stress. The higher water stress was associated with the high penetration time meaning firmer texture of potatoes.

Colour of potato tubers as affected by types of farming, water stress and bulk density

Data presented in Table (6) of indicated that potato tubers cultivated by organic farming exhibited significantly higher $a^{*}$ value (red colour), higher $b^{*}$ value (yellow colour) and high chroma value than tubers cultivated by conventional farming. On the other hand, potato tubers cultivated by conventional farming had significantly higher L* value (lightness) and hue value as compared with potato tubers cultivated by organic farming. Water stress of $50 \%$ gave potato tubers that possessed significantly higher $L^{*} a^{*} b^{*}$ and Chroma.

Data presented in Table (6) indicated that bulk density of potato tubers revealed significantly higher values for tubers cultivated by conventional farming than their counterparts cultivated by organic farming. It was obvious that bulk density of potato tubers were found to be significantly affected by the water stress. In other words, as water stress increased as the bulk density of potato tubers wad increased. According to Lynch et al. (1995), a year x moisture stress interaction $(\mathrm{P}>0.05)$ for fry colour of potato suggests that the influence of moisture stress on fry colour can be modified by other environmental factors. Meanwhile, it was reported that decreasing soil water potential (drier soil) was associated with progressively darker fry colors of potato slices at harvest and postharvest. The effect of imposed water stress on tuber stem end reducing sugar concentration was most pronounced harvest ( Eldredge et al, 1996).

Table 6. Colour Hunter parameters and bulk density of potato tubers cultivated by organic and conventional farming at different values of water stress

\begin{tabular}{|c|c|c|c|c|c|c|c|}
\hline \multirow{2}{*}{\multicolumn{2}{|c|}{ Treatment }} & \multicolumn{5}{|c|}{ Colour parameters } & \multirow[t]{2}{*}{ Bulk density } \\
\hline & & $\mathbf{L}^{*}$ & $a^{*}$ & $\mathbf{b}^{*}$ & $C^{*}$ & $\mathbf{h} *$ & \\
\hline \multicolumn{2}{|l|}{ Organic farm. } & $55.82 \mathrm{~b}$ & $7.46 \mathrm{a}$ & $18.01 \mathrm{a}$ & $27.43 \mathrm{a}$ & $75.04 b$ & $0.642 \mathrm{a}$ \\
\hline \multicolumn{2}{|c|}{ Conventional farm } & $58.85 \mathrm{a}$ & $7.07 \mathrm{~b}$ & $17.68 \mathrm{~b}$ & $26.11 \mathrm{~b}$ & $75.68 \mathrm{a}$ & $0.572 b$ \\
\hline \multicolumn{2}{|c|}{ L.S.D 0.05} & 1.78 & 0.31 & 0.004 & 0.004 & 0.005 & $2 * 10-5$ \\
\hline \multicolumn{8}{|l|}{ Water stress } \\
\hline \multicolumn{2}{|l|}{$100 \%$} & $59.58 \mathrm{a}$ & $6.64 c$ & $17.62 b$ & $26.09 \mathrm{~d}$ & $76.33 a$ & $0.630 \mathrm{a}$ \\
\hline \multicolumn{2}{|l|}{$85 \%$} & $56.11 \mathrm{~b}$ & $7.16 b$ & $17.29 \mathrm{~d}$ & $26.24 b$ & $74.72 d$ & $0.615 b$ \\
\hline \multicolumn{2}{|l|}{$60 \%$} & $56.96 \mathrm{ab}$ & $7.34 \mathrm{~b}$ & $17.42 \mathrm{c}$ & $26.11 \mathrm{c}$ & $75.04 c$ & $0.595 \mathrm{c}$ \\
\hline \multicolumn{2}{|l|}{$50 \%$} & $56.69 \mathrm{ab}$ & $7.92 \mathrm{a}$ & $19.06 \mathrm{a}$ & $28.66 \mathrm{a}$ & $75.36 \mathrm{~b}$ & $0.590 \mathrm{~d}$ \\
\hline \multicolumn{2}{|l|}{ L.S.D 0.05} & 2.52 & 0.44 & 0.006 & 0.007 & 0.006 & $3 * 10-5$ \\
\hline \multicolumn{8}{|l|}{ Interactions: } \\
\hline Farming type & Water stress & $\begin{array}{l}\text { L* } \\
\text { density }\end{array}$ & $a^{*}$ & $\mathbf{b}^{*}$ & $C^{*}$ & h* & Bulk \\
\hline \multirow{4}{*}{ organic } & 100 & $56.54 \mathrm{~b}$ & $6.57 \mathrm{c}$ & $17.70 \mathrm{~d}$ & $27.20 \mathrm{c}$ & $73.78 \mathrm{~g}$ & $0.68 \mathrm{a}$ \\
\hline & 85 & $55.70 \mathrm{~b}$ & $7.45 \mathrm{bc}$ & $17.18 \mathrm{~g}$ & $24.60 \mathrm{~h}$ & $74.60 \mathrm{e}$ & $0.64 \mathrm{~b}$ \\
\hline & 60 & $57.07 \mathrm{~b}$ & $6.87 \mathrm{c}$ & $16.89 \mathrm{~h}$ & $25.32 \mathrm{e}$ & $73.88 \mathrm{f}$ & $0.63 \mathrm{c}$ \\
\hline & 50 & $53.98 \mathrm{~b}$ & $8.96 \mathrm{a}$ & $20.29 \mathrm{a}$ & $32.62 \mathrm{a}$ & $77.92 \mathrm{~b}$ & $0.62 \mathrm{~d}$ \\
\hline \multirow{4}{*}{ conventional } & 100 & $62.62 \mathrm{a}$ & $6.71 \mathrm{c}$ & $17.55 \mathrm{e}$ & $24.98 \mathrm{f}$ & $78.88 \mathrm{a}$ & $0.58 \mathrm{f}$ \\
\hline & 85 & $56.53 \mathrm{~b}$ & $6.88 \mathrm{c}$ & $17.40 \mathrm{f}$ & $27.88 \mathrm{~h}$ & $74.84 \mathrm{~d}$ & $0.59 \mathrm{e}$ \\
\hline & 60 & $56.85 \mathrm{~b}$ & $7.82 \mathrm{~b}$ & $17.96 \mathrm{~b}$ & $26.90 \mathrm{~d}$ & $76.20 \mathrm{c}$ & $0.56 \mathrm{~g}$ \\
\hline & 50 & $59.41 \mathrm{ab}$ & $6.88 \mathrm{c}$ & $17.83 \mathrm{c}$ & $24.70 \mathrm{~g}$ & $72.80 \mathrm{~h}$ & $56 \mathrm{~g}$ \\
\hline \multicolumn{2}{|l|}{ L. S. D. 0.5} & 3.56 & 0.62 & 0.01 & 0.01 & 0.01 & $5 \times 10^{-5}$ \\
\hline - L = Lightness & $\begin{aligned}(+) & =\text { Red } \\
(-) & =\text { Green }\end{aligned}$ & $\begin{array}{l}\mathrm{b}(+)=\text { yellow } \\
(-) \text { Blue }\end{array}$ & $\mathrm{c}=$ Chrom & $\mathrm{h}=\mathrm{Hu}$ & & & \\
\hline
\end{tabular}

Means in a column not sharing the same superscript are significantly different at $\mathrm{P}>0.0$ 
Gross chemical composition of potato tubers as affected by type of farming and water stress

Table (7) shows that crude protein content of potato tubers cultivated by organic farming increased as water stress decreased from $100 \%$ to $60 \%$. A drastic decline in protein content was observed at $90 \%$ water stress. On the other hand, protein content of potato tubers cultivated by conventional farming varied from 7.27 (100\%) water stress to 15.87 (80\% water stress).

Ash content of potato tubers cultivated by organic farming ranged between $5.31 \%$ (60\% water stress) to 5.82 (85\% water stress) as shown in Table (7). Potato tubers cultivated by conventional farming possessed ash content varied from $5.42 \%(85 \%$ water stress $)$ to 6.15 (50\%water stress)

Data given in Table (7) indicated that total lipid content ranged from $1.79 \%$ (60\% water stress) to $1.96 \%$ $(100 \%$ water stress) for potato tubers cultivated by conventional farming. On the other hand, total lipid content ranged from $1.13 \%$ (50\% water stress) to $1.72 \%$
(100\% water stress) for potato tubers cultivated by conventional farming.

Total carbohydrate content was found to decrease as the water stress decreased from $100 \%$ to $60 \%$ The highest total carbohydrate content (82.76) was observed at $50 \%$ water stress for potato tubers cultivated by organic farming (Table7). In addition, potato tubers cultivated by conventional farming had total carbohydrate content varied from $78.16 \%$ (80\% water stress) to $86.23 \%(100 \%$ water stress $)$ as shown in Table 7.

Table (7) shows that potato tubers cultivated by conventional (inorganic) farming exhibited higher oil retention as compared to their counterparts cultivated by organic farming. The oil retention ranged between $13.11 \%$ and $24.55 \%$ and between $19.92 \%$ and $30.99 \%$ for the French fries cultivated by organic and conventional farming, respectively. Consequently, organic farming of potato results in lowering the oil retention in French fries. Such an effect is considered as an advantage with respect to health beneficial point of view.

Table 7. Gross chemical composition (on dry weight basis) of potato tubers cultivated by organic and conventional farming at different levelss of water stress

\begin{tabular}{|c|c|c|c|c|c|c|}
\hline \multirow{2}{*}{\multicolumn{2}{|c|}{ Treatment }} & \multicolumn{4}{|c|}{ Chemical composition } & \multirow[b]{2}{*}{ Oil retention $\%$} \\
\hline & & $\begin{array}{c}\text { Total } \\
\text { carbohydrate\% }\end{array}$ & Protein \% & Ash\% & Total lipids\% & \\
\hline \multicolumn{2}{|c|}{ Organic farm. } & $77.34 \mathrm{~b}$ & $15.60 \mathrm{a}$ & $5.48 b$ & $1.87 \mathrm{a}$ & $18.00 \mathrm{~b}$ \\
\hline \multicolumn{2}{|c|}{ Conventional farm } & $81.21 \mathrm{a}$ & $12.12 b$ & $5.84 a$ & $1.39 \mathrm{~b}$ & $27.93 a$ \\
\hline \multicolumn{2}{|l|}{ L.S.D 0.05} & 0.0062 & 0.0036 & 0.0095 & 0.0036 & 0.084 \\
\hline \multicolumn{7}{|l|}{ Water stress } \\
\hline \multicolumn{2}{|l|}{$100 \%$} & $82.69 \mathrm{a}$ & $10.92 \mathrm{c}$ & $5.52 \mathrm{~d}$ & $1.84 \mathrm{a}$ & $10.92 \mathrm{c}$ \\
\hline \multicolumn{2}{|l|}{$85 \%$} & $76.72 \mathrm{c}$ & $16.49 \mathrm{~b}$ & $5.63 c$ & $1.73 \mathrm{~b}$ & $16.49 \mathrm{~b}$ \\
\hline \multicolumn{2}{|l|}{$60 \%$} & $75.60 d$ & $17.40 \mathrm{a}$ & $5.70 \mathrm{~b}$ & $1.48 \mathrm{c}$ & $17.40 \mathrm{a}$ \\
\hline \multicolumn{2}{|l|}{$50 \%$} & $82.09 \mathrm{~b}$ & $10.62 d$ & $5.81 \mathrm{a}$ & $1.47 \mathrm{~d}$ & $10.62 d$ \\
\hline \multicolumn{2}{|l|}{ L.S.D 0.05} & 0.0117 & 0.016 & 0.0126 & 0.0051 & 0.0669 \\
\hline \multicolumn{7}{|l|}{ Interaction: } \\
\hline \multirow[t]{2}{*}{$\begin{array}{c}\text { Farming } \\
\text { type }\end{array}$} & $\begin{array}{l}\text { Water } \\
\text { stress }\end{array}$ & $\begin{array}{c}\text { Total } \\
\text { carbohydrate\% }\end{array}$ & Protein \% & Ash\% & Total lipids\% & Oil retention \% \\
\hline & $100 \%$ & $79.11 \mathrm{~d}$ & $14.59 \mathrm{~d}$ & $5.32 \mathrm{~g}$ & $1.96 \mathrm{a}$ & $18.80 \mathrm{e}$ \\
\hline \multirow{3}{*}{ organic } & $85 \%$ & $75.27 \mathrm{~g}$ & $17.11 \mathrm{~b}$ & $5.82 \mathrm{c}$ & $1.94 b$ & $13.11 \mathrm{~g}$ \\
\hline & $60 \%$ & $72.19 \mathrm{~h}$ & $20.71 \mathrm{a}$ & $5.31 \mathrm{~g}$ & $1.79 \mathrm{~d}$ & $24.55 \mathrm{c}$ \\
\hline & $50 \%$ & $82.76 \mathrm{~b}$ & $9.96 \mathrm{~g}$ & $5.47 \mathrm{e}$ & $1.81 \mathrm{c}$ & $15.54 \mathrm{f}$ \\
\hline \multirow{4}{*}{$\begin{array}{c}\text { convention } \\
\text { al }\end{array}$} & $100 \%$ & $86.23 a$ & $7.24 \mathrm{~h}$ & $5.71 d$ & $1.72 \mathrm{e}$ & $30.99 a$ \\
\hline & $85 \%$ & $78.16 \mathrm{f}$ & $15.87 \mathrm{c}$ & $5.42 \mathrm{f}$ & $1.52 \mathrm{f}$ & $19.92 d$ \\
\hline & $60 \%$ & $79.02 \mathrm{e}$ & $14.08 \mathrm{e}$ & $6.09 \mathrm{~b}$ & $1.18 \mathrm{~g}$ & $30.96 \mathrm{a}$ \\
\hline & $50 \%$ & $81.42 \mathrm{c}$ & $11.29 \mathrm{f}$ & $6.15 a$ & $1.13 \mathrm{~h}$ & $29.84 b$ \\
\hline
\end{tabular}

Means in a column not sharing the same superscript are significantly different at $\mathrm{P}>0.0$ 


\section{REFERENCES}

Allen, R.G., L. S. Pereira, D. Raes and M. Smith. 1998. Crop Evapotranspiration Guidelines for Computing Crop Water Requirements. FAO Irri. and Drain. Paper No. 56, FAO, Rome, Italy, 300.

Al Hanafy, M. H. 2016. Effect of some natural resources on growth, yiels and quality of onion crop. Thesis of Master from Environmental Studies and Research Institute -University of Sadat City.

AOAC. 2003. Official Methods of Analytical Chemsts, International, Arlington, Virginia, USA.

Badr, M.A., S.D.Abou Hussein, W.A. El-Tohamy and N.Gruda. 2010. Efficiency of subsurface drip irrigation for potato production under different dry stress conditions. Gesunde Pflanzen. 62: 63-70.

Badr, M.A., W.A., El-Tohamy, A.M. Zaghloul. 2012. Yield and water use efficiency of potato grown under different irrigation and nitrogen levels in an arid region. Agric. Water Manage. 110: 9-15.

Burton, W. g. 1989. The Potato ( $3^{\text {rd }}$ ED.). Harlow, Essex: Longman Scientific and Technical Longman Group.

Carmen, F., A. Moschella, F. Miselli, B. Parisi, G. Versini, P. Ranalli and P. Bagnaresi. 2007. Evaluation of marcers for the traceability of potato tubers grown in an organic versus conventional regime. Science Food Agric. 87: 1330 -1336 .

Eldredge, E. P., Z. A. Holmes, A. R. Mosley, C. C. Shoch, and T. D. Stieber.1996. Effects of transitory water stress on potato tuber stem - end reducing sugar and fry color. Am. Potato J. 73: 517-530

Esitken, A. and M. Turan. 2003. Alternating magnetic field effect on yield and plant nutrient element composition of strawberry (Fragaria $\mathrm{x}$ ananassa cv. camarosa). Acta Agric. Scandinavica. Section B,Soil Plant Sci. 54: 135139.

Kramer, A. and Twigg, B.A.1970. Quality-3 rd Ed. AVI Publishing Co. West. Port Conn. London, England, pp. $120-154$.
Hassan, A.A., A.A. Sarkar, M.H. Ali and, N.N. Karim. 2002. Effect of deficit irrigation at different growth stages on the yield of potato. Pakistan J. Biological Sci., 5 (2): 128-134.

Hassan panah, D., 2010. Evaluation of potato cultivars for resistance against water deficit stress under in vivo conditions. Potato Res. 5: 383-392.

Howell, T.A., R.H.Cuenca, K.H.Solomon. 1990. Crop Yield Response, In: Hoffman, et al. (Eds.), Management of Farm Irrigation Systems. ASAE, p. 312.

Kizito, K. F., M. M. Yossef, M. H. Abdel - Aal , and M. H. H. Ragab. 2015. Quality attributes of French Fries: Factors affecting there on - A Review Alexandria J. Food Sci. Technology, 12: 11 -28.

Loon, C. D van. 1981. The effect of water stress on potato growth, development and yield. Am. Potato J., 58:51-69.

Lynch, M., Conery, J. and R. Buerger. 1995. Mutation accumulation and the extinction of small populations. Am Nat, 146: 489-518.

Mouille, B. B. and R. Charrondiere. 2009. Nutrients and antinutrients in potatoes.

J. Food Composition and Analysis, 22: 494 - 502.

Rangana, S. 1977. Manual of Analysis of Fruit and Vegetable Products. Tata Mc Graw - Hill pun. Co. Ltd. New Delhi.

Sharara, M.S. and I.M. Ghoneim. 2015. Evaluation of five potato varieties for producing French Fries. Alexandria J. Food Sci. and Technology, 12: 1-9.

Steel, R.G. and J. H. Torrie. 1980. Principles and Procedures of Statistics. 2 nd Ed. Mc Graw Hill., New York, USA.

Tanner, C.B., T.R. Sinclair. 1983. Efficient water use in crop production: Research or Research. In: H.M.Taylor,. (Ed.), Limitations to Efficient Water Use in Crop Production. ASA, Madison, WI, 1-27.

Wegener, C.b., H. U. Jansen. 2015. Bioactive Compounds in potatoes: Accumulation under drought stress conditions. Functional Food in Health and Disease, 5: 108 - 116.

Zarzyniska, K . and M . Pietraszko. 2015. Influence of climatic conditions on development and yield of potato plants growing under organic and conventional systems in Poland. Am J. Potato Res., 92: 511 - 517. 


\section{الملضص العرب}

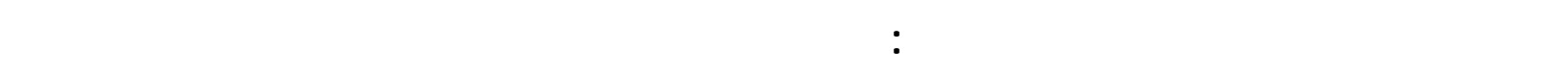

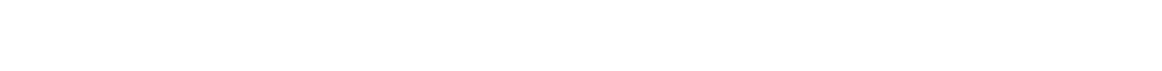

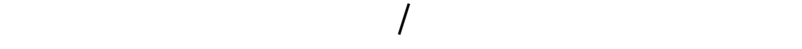

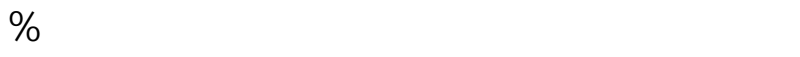

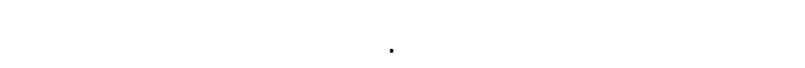

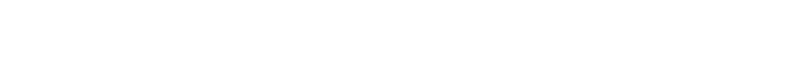

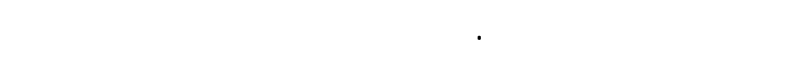

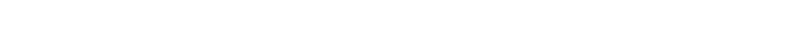

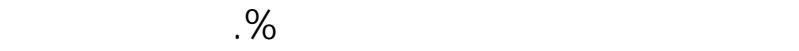
النتائج وجود بعضية الاختلافلت الضئيلة في التركيب

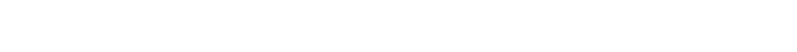

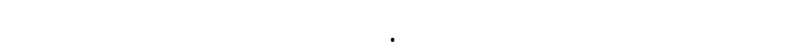
هناك تأثيرات معنوية لأي من طريقة الزراعة أو مستوى

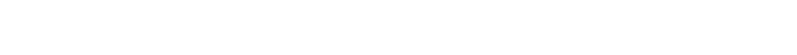

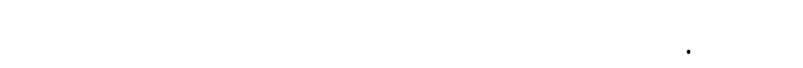
بالطريقة العضوية عند تحميرها في صورة أصانع قد المدات

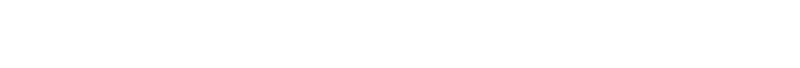
زراعتها بالطريقة القليية.
لجريت هذه الدرلمة بالمزرعة التجريبية لجلمعة مدينة

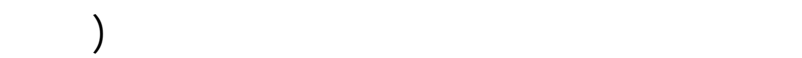

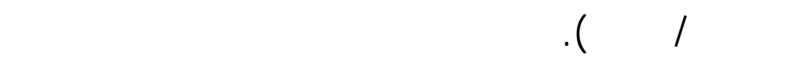

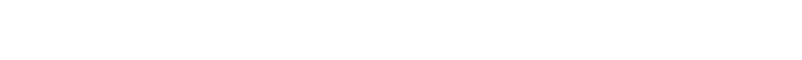

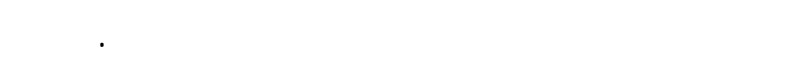

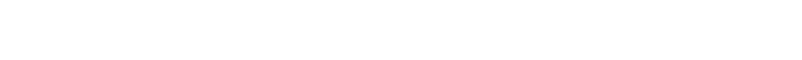

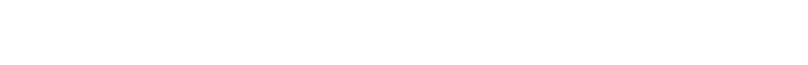

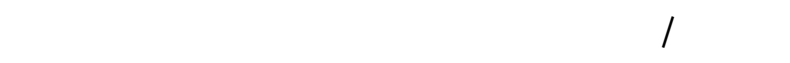

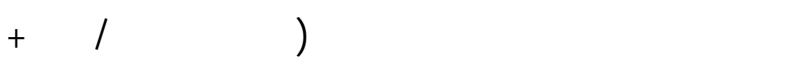

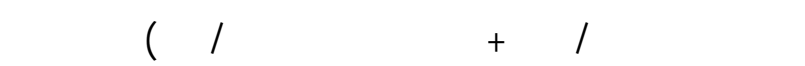

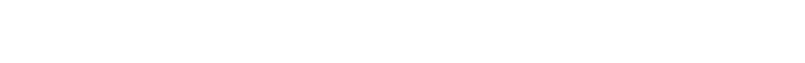

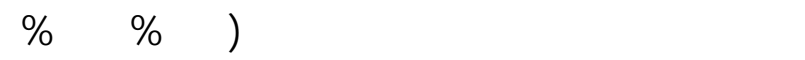

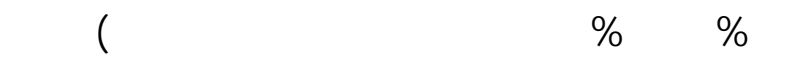
المحصول ومكوناته وجولة الاصايع المحمرة للططلس.

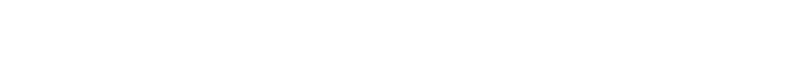

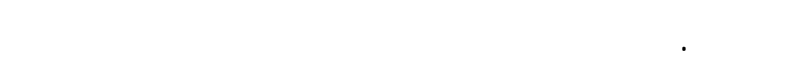
لجهاد مائي . . ا\% عند زراعة الططلس بالطريقة القليية 